\section{Response to: 'Depression and anxiety associate with less remission after 1 year in rheumatoid arthritis' by Boer et al}

We thank Boer et al for their interesting report ${ }^{1}$ validating our findings of depression and anxiety as strong negative predictors of remission in rheumatoid arthritis (RA). ${ }^{2}$

Depression and anxiety are frequent disorders among patients with inflammatory arthritides, ${ }^{34}$ and emphasis on these conditions may be important in a treat-to-target strategy, not only in the shared decision-making of a treatment target between patient and rheumatologist, but also in the decision of type of treatment target. That is, as baseline depression and anxiety are found to be associated with more subjectively weighted measures, but not acute phase reactants and swollen joint count during follow-up, ${ }^{12}$ alternative (composite) measures of disease activity as well as target values should be considered, in accordance with recommendation number 5 in the treat-to-target recommendations. ${ }^{5}$

Boer et al used Disease Activity Score 44 remission, and we used Disease Activity Score 28, Simplified Disease Activity Index, Clinical Disease Activity Index, American College of Rheumatology/European League Against Rheumatism Boolean and modified Disease Activity index for PSoriatic Arthritis remission (patients with psoriatic arthritis were also included in our study), with similar findings of baseline depression and anxiety as strong negative predictors of remission. Subjective weighted measures (patients' global assessment, tender joint count, pain) are included in all these composite scores and may cause misinterpretation of RA disease activity also due to impaired pain perception ${ }^{6}$ in patients with depression and anxiety.

We fully agree with Boer $e t$ al that depression and anxiety may influence important treatment decisions in RA and that it is of importance to take this into consideration to prevent increased medical costs as well as patient burden due to unnecessarily intensified treatment regimens.

Brigitte Michelsen, ${ }^{1,2,3}$ Tore K Kvien $^{1}$
${ }^{1}$ Department of Rheumatology, Diakonhjemmet Hospital, Oslo, Norway ${ }^{2}$ Department of Rheumatology, Hospital of Southern Norway Trust, Kristiansand, Norway

${ }^{3}$ Norwegian University of Science and Technology, Trondheim, Norway

Correspondence to Dr Brigitte Michelsen, Department of Rheumatology, Diakonhjemmet Hospital, Oslo N-0319, Norway; brigitte_michelsen@yahoo.no

Handling editor Josef S Smolen

Competing interests None declared.

Provenance and peer review Commissioned; internally peer reviewed.

(c) Article author(s) (or their employer(s) unless otherwise stated in the text of the article) 2019. All rights reserved. No commercial use is permitted unless otherwise expressly granted.

\section{Check for updates}

To cite Michelsen B, Kvien TK. Ann Rheum Dis 2019;78:e2.

Received 8 January 2018

Accepted 9 January 2018

Published Online First 22 January 2018

\section{Linked}

http://dx.doi.org/10.1136/annrheumdis-2017-212867

Ann Rheum Dis 2019;78:e2. doi:10.1136/annrheumdis-2017-212910

\section{REFERENCES}

1 Boer AC, Huizinga TWJ, van der Helm-van Mil AHM, et al. Depression and anxiety associate with less remission after 1 year in rheumatoid arthritis. Ann Rheum Dis 2019;78:e1.

2 Michelsen B, Kristianslund EK, Sexton J, et al. Do depression and anxiety reduce the likelihood of remission in rheumatoid arthritis and psoriatic arthritis? Data from the prospective multicentre NOR-DMARD study. Ann Rheum Dis 2017;76:1906-10.

3 Matcham F, Rayner L, Steer S, et al. The prevalence of depression in rheumatoid arthritis: a systematic review and meta-analysis. Rheumatology 2013;52:2136-48.

$4 \mathrm{McDonough} E$, Ayearst $\mathrm{R}$, Eder $\mathrm{L}$, et al. Depression and anxiety in psoriatic disease: prevalence and associated factors. J Rheumatol 2014;41:887-96.

5 Smolen JS, Breedveld FC, Burmester GR, et al. Treating rheumatoid arthritis to target: 2014 update of the recommendations of an international task force. Ann Rheum Dis 2016:75:3-15.

6 Edwards RR, Cahalan C, Calahan C, et al. Pain, catastrophizing, and depression in the rheumatic diseases. Nat Rev Rheumatol 2011:7:216-24. 